ESJ Social Sciences

\title{
Moderating Effect of Illiquidity on The Relationship Between Momentum and Equity Returns in The Kenyan Capital Markets
}

\author{
Peter Kamau Ndichu \\ Dr. Robert Kisavi Mule \\ Department of Accounting and Finance, Maseno University, Kenya
}

Doi:10.19044/esj.2021.v17n41p14

Submitted: 18 September 2021

Accepted: 23 December 2021

Published: 31 December 2021
Copyright 2021 Author(s)

Under Creative Commons BY-NC-ND

4.0 OPEN ACCESS

Cite As:

Ndichu P.K. \& Mule R.K. (2021). Moderating Effect of Illiquidity on The Relationship Between Momentum and Equity Returns in The Kenyan Capital Markets. European Scientific Journal, ESJ, 17 (41), 14. https://doi.org/10.19044/esj.2021.v17n41p14

\section{Abstract}

This paper sought to examine the moderating effect of illiquidity on the relationship between momentum and equity returns in the Kenyan capital markets. Previous studies have shown that illiquidity has a time-varying effect on momentum strategies, but little is known whether illiquidity has a moderating effect on the relationship between momentum and equity returns in Kenyan capital markets. A longitudinal research design was used for this study to examine the causal inference. Data comprised of monthly transactions on the 20 equities used in the formulation of the NSE 20 share index over the period between Jan 2009 and up to March 2018 which formed 111 data points. $\mathrm{ADF}$ and PP results showed that Returns and momentum are stationary at levels while illiquidity was stationary at first difference. The error correction term was negative and statistically significant with or without the moderator. Results indicate that without a moderator percentage increase in momentum is linked to a $0.0000313 \%$ increase in returns in the short run. The study further shows that the effect of momentum on equity returns is moderated by illiquidity using a t-test. R2 changed from 0.427 to 0.4337 indicating a change of 0.006 at $0.05 \%$ significant level suggesting that illiquidity moderates the relationship between momentum and equity returns in the Kenyan capital markets. 
Keywords: Illiquidity, Momentum, Equity Returns

\section{Introduction}

Globally capital markets play an important role in promoting economic activity worldwide by facilitating and diversifying firms' access to finance, (Association of Chartered Certified Accountants, 2012). In the period between 2009-2014, capital markets have experienced a period of unprecedented change primarily due to a wide-ranging post-crisis regulatory regime and a challenging macro-economic environment (Wyman, 2014).

Illiquidity refers to the inability to transact large quantities of assets and or securities due to a shortage of interested buyers, (Dalgaard, 2009). Illiquidity can also be defined as the degree of friction in a given exchange market, where there is a measurable extent of the cost of exchange, agents' price distortion, and movements (Amihud, Mendelson \& Pedersen, 2005). Momentum on the other hand refers to the tendency of assets with good or bad recent performance to continue overperforming or underperforming in the near future, (Vayanos and Woodley 2013).

Momentum is the tendency of assets with good or bad recent performance to continue overperforming or underperforming in the near future, (Vayanos and Woodley 2013). Moskowitz, et. al, (2013), define momentum as the tendency of investments, in every market and asset class, to exhibit persistence in their relative performance for some time. One of the reasons for momentum is that higher returns are compensation for some unique risk associated with investments that have recently outperformed, (Moskowitz, et. al 2013). The second reason is the existence of momentum seems to challenge the efficient market hypothesis that past price behavior provides no information about future behavior. In other words, momentum is associated with some inefficiency in markets, perhaps due to investor behavior (Moskowitz, et. al 2013).

The empirical literature has provided evidence of returns attributed to momentum in international markets, (Fama and French, 2012; Choi, 2014; Muhairi, 2011; Norieka and Barauskas, 2010; Nguyen and Fraulo, 2010; Gutierrez et.al, 2004; Konokonglu, 2010; Nørregård, 2008; Gaunt and Schinider, 2012) except Japan (Fama and French, 2012). Choi, (2014) asserts that alternative strategies constructed by the physical momentum achieve expected better returns and reward-risk measures than those of the traditional contrarian strategy on a weekly scale. Winners on the other hand continue to outperform losers, with performance persistence continuing for periods of three to twelve months which indicates the occurrence of momentum in the short-run (Muhairi, 2011) and strongest around the 6-12-month mark (Gaunt and Schinider, 2012). Gutierrez et.al, 2004 posits that momentum profits increase as the lagged market return increases and at high levels of lagged 
market returns, the profits diminish but are not eliminated. In conclusion, Gutierrez et.al (2004) argue that momentum strategies depend critically on the state of the market and that momentum profits are reversed in the long run.

Capital markets play a vital role in Africa's future. The continent's financial markets have remained resilient and innovative amid slowing worldwide growth after the synchronized upturn of 2017. However, they remain fragmented and shallow compared to their equivalents in Latin America and Asia (Adesina, 2018). Kenyan equities were ranked the fourthbest performer as a group in 2013, according to the global indices of the USbased index provider Morgan Stanley Capital International (MSCI). The MSCI Kenya Index increased $43.58 \%$ on the year, fourth-best among country indexes, after Bulgaria (91.55\%), United Arab Emirates (UAE) (79.02\%), and Argentina (68.97\%). The performance declined in 2014, to $23.38 \%$; 2015 ($18.34 \%)$; 2016(1.11\%), increased in 2017 to $35.97 \%$ and a decline again in $2018(-12.51 \%)$ and in 2019 the performance was 48.73\% (MSCI Kenya Index, 2020) indicating a mixed performance of the equity market. Kenya's Market Capitalization accounted for $26.1 \%$ of its Nominal GDP in Dec 2019 , compared with a percentage of $23.6 \%$ in the previous year. (CEIC, 2020) This is a dismal performance noting that a Stock market capitalization of about 50 percent of GDP and more is an indication of a welldeveloped stock market. Previous years also present performance below50\%, for instance in 2009(29.1\%), 2010(36.8\%), 2011(23.4\%), 2012(29.8\%), 2013(40\%), 2014(42.6\%), 2015(32.6), 2016(27.5\%) and 2017(30.8\%) (World Bank, 2020).

According to the Capital Market Authority Kenya (CMA) 2018, in the quarter to June 2018, average quarterly equity market liquidity stood at 2.17 percent, compared to 1.83 percent registered in the quarter to March 2018, indicating a $0.34 \%$ decrease in turnover ratio in the equities market mainly attributable to a 22.91 decrease in turnover between Q1/2018 and Q2/2018, this shows how Kenya like other emerging market economies is characterized by a capital market with low liquidity levels averaging between seven percent and nine percent per annum between 2016 and 2018, this is also evident during the period 1993 to 2019 where the average period was $4.95 \%$ which is way below the global average of 26.20\% (World Bank, 2020).

Empirical evidence has shown that the profitability of the momentum trading strategy strongly varies with the state of market illiquidity, consistent with behavioural models of investors' expectations. (Avramov et.al,2013; Aziz and Ansari, 2014; Orlov, 2016; Butt and Virk, 2017) it therefore would be interesting to further clarify whether illiquidity has a moderating effect on the relationship between momentum and equity returns in the Kenyan capital market. 


\section{Hypothesis}

The following hypothesis was tested

$H_{a}$, illiquidity has no moderating effect on the relationship between momentum and equity returns.

\subsection{Review of Literature}

One of the important characteristics of an efficient market is the ease with which financial assets can be traded (Lo and Khandani, 2009). Liquidity is related to the ease of trading security, several extensions of the neoclassical framework have been proposed to account for trading activity since the standard frictionless asset-pricing models cannot address the issue directly, (Lo and Khandani, 2009). For example, the seller of a hard-to-trade asset may incur an inventory cost that arises because a buyer may not be present at the time a seller needs to cash out, and the seller may be forced to enter into a transaction with a designated market maker. The market maker will charge the seller a fee by giving the seller an amount less than the fair price of the security to take on the risk of holding that security until a buyer is found, (Lo and Khandani, 2009).

According to Reilly and Brown, (2013) Illiquidity is a risk factor in determining returns. Risk factors are all the factors that contribute to a given degree to the returns of the stock, their effect is beta specific. The main risk factors in determining stock returns are business risk, financial risk (leverage), liquidity (Illiquidity) risk, exchange rate risk, and country (political risk). Amihud, Mendelson and Pederson, (2005) contends that liquidity as a concept is complex, and argues various sources of illiquidity; one of the sources of illiquidity is exogenous cost such as brokerage fees, order-processing costs, or transaction taxes. Every time security is traded, the buyer and/or seller incur a transaction cost; in addition, the buyer anticipates further costs upon a future sale, and so on, throughout the life of the security. Amihud, Mendelson and Pederson, (2005) further posits another source of illiquidity as demand pressure and inventory risk. Demand pressure arises because not all agents are present in the market at all times, which means that if an agent needs to sell a security quickly, then the natural buyers may not be immediately available. As a result, the seller may sell to a market maker who buys in anticipation of being able to later lay off the position. The market maker, being exposed to the risk of price changes while he holds the asset in inventory, must be compensated for this risk - a compensation that imposes a cost on the seller (Amihud, Mendelson, and Pederson, 2005).

Another source of illiquidity according to Amihud, Mendelson, and Pederson, (2005) is the difficulty of locating a counterparty who is willing to trade particular security, or a large quantity of a given security. Further, once a counterparty is located, the agents must negotiate the price in a less than 
perfectly competitive environment since alternative trading partners are not immediately available. This search friction is particularly relevant in over-thecounter (OTC) markets in which there is no central marketplace. Amihud, Mendelson and Pederson, (2005) conclude that trading security may be costly because the traders on the other side may have private information for example, the buyer of stock may worry that a potential seller has private information that the company is losing money, and the seller may be afraid that the buyer has private information that the company is about to take off. Then, trading with an informed counterparty will end up in a loss. Costs of illiquidity should affect securities prices if investors require compensation for bearing them and also liquidity varies over time, risk-averse investors may require compensation for being exposed to illiquidity and as such investors need to know them while designing their investment strategies and if liquidity costs and risks affect the required return by investors, they affect corporations' cost of capital and, hence, the allocation of the economy's real resources, (Amihud, Mendelson, and Pederson, 2005).

Various authors (Glosten and Milgrom (1985), Easley and O'Hara (1987), and Easley, Hvidkjaer, and O'Hara (2002), Amihud, Mendelson, and Pedersen (2005)) have developed the view of transaction cost causing illiquidity, moreover, the literature on the impact of illiquidity on asset prices seems to divide into two distinct perspectives; one approach posited by (Amihud and Mendelson (1986), Eleswarapu and Reinganum (1993), Eleswarapu (1997), and Aragon (2004)) argued that liquidity as just another deterministic characteristic of security such as a transaction cost, and because economic agents' preferences are based on an asset's net return, net of transaction costs, assets with higher costs must offer a higher gross expected return, ceteris paribus. Alternatively, Chacko (2005), argued that if trading costs exist but are not time-varying, the buyer or seller of security can incorporate these costs into his decision-making process, and such costs should have no first-order effects on asset prices in equilibrium, in line with this reasoning, Vayanos (1998) and Vayanos and Vila (1999) argued that illiquidity-related costs can only be a second-order determinant of asset prices since bid-offer spreads are so small relative to typical equilibrium risk premia. Further models by Pastor and Stambaugh (2003) and Acharya and Pedersen (2005) examined the systematic nature of illiquidity risk and posited that illiquidity should not matter in equilibrium because agents would simply reduce the impact of such costs by adjusting their portfolios less frequently. In conclusion, Hasbrouck (2005), noted that the extent to which agents do this is unclear since observed levels of trading volume are much higher than those predicted by standard equilibrium asset-pricing models. But if trading costs are time-varying and unknown in advance, then their impact on equilibrium 
asset prices can be more substantial because of the additional risks they impose on investors if such risks were not diversifiable or readily insurable.

Empirically, various authors find a significant positive effect of bidask spreads in explaining cross-sectional stock returns. However, there is limited literature on the moderating effect of illiquidity on the relationship between momentum and equity returns in the Kenyan Capital Market.

Momentum is one of the most debated yet the most popular factor influencing equity market returns, (Srivastava et. al,2019) Momentum as defined by Berger et.al (2009) is the tendency of investments, in every market and asset class, to exhibit persistence in their relative performance for some time. When applied to stock picking, momentum is about relative performance among stocks, and not about overall trends in the market. It works whether a market is in an upswing or downswing. Momentum can be used to identify securities likely to outperform, making it a powerful investment tool. It is also negatively correlated to value investing, making it an effective diversification component. Regardless of investment philosophy, virtually all investors can expect improved risk-adjusted returns by including momentum (Berger et.al 2009).

According to (Gosalia and Lefebvre, 2013) momentum is the rate of acceleration of a security's price or volume. The idea of momentum in securities is that their price is more likely to keep moving in the same direction than to change directions. In technical analysis, momentum is considered an oscillator and is used to help identify trend lines. Once a momentum trader sees acceleration in a stock's price, earnings or revenues, the trader will often take a long or short position in the stock in the hope that its momentum will continue in either an upward or downward direction. This strategy relies on short-term movements in a stock's price rather than fundamental value, and it is not recommended for novices. The existence of momentum leads to the momentum effect.

Jegadeesh and Titman (1993) presented evidence of momentum patterns in stock prices, which create an opportunity for investors to earn significant profits by buying past (winner stocks) that have performed relatively well (high returns) over the past three to twelve months and selling past (loser stocks) that have performed relatively poorly (low returns) over the past three to twelve months.

If stock prices either overreact or underreact to information, then profitable trading strategies that select stocks based on their past returns will exist. DeBondt and Thaler (1985) documented that past losers over three- to five-year periods outperform past winners over the subsequent three to five years. Jegadeesh (1990) and Lehmann (1990) found that losers over the past one week to one month outperform winners over the next one week to one month. These studies of very long-term and very short-term returns find 
profitable contrarian strategies and generally led to the conclusion that stock prices overreact to information. (Jagadeesh and Titman, 2011).

In international Markets, Chan, Hameed, and Tong (2000) found the momentum effect existed in the national stock market indices of 23 countries for the period 1980 to 1995. Nine are from the Asia-Pacific, eleven are from Europe, and two are from North America (Canada and the U.S.), where the difference between the returns of winner and loser portfolios is at least 0.25 percent per week. Bhojraj and Swaminathan (2001) further confirmed the qualitative results by Chan, Hameed, and Tong (2000) for their total sample of 38 countries over the period 1975 to 1999 result, where strong momentum is evident up to three quarters after the portfolio formation date, with winners outperforming losers significantly by $1.40 \%$ to $2.33 \%$ per quarter over the next 3 quarters. Bacmann, Dubois, and Isakov (2001) documented the profitability of momentum strategies in member countries of the G-7 i.e., USA, Canada, Japan, the UK, France, Germany, and Italy. While Griffin, Susan, and Martin (2003) find that momentum profits for Asia are decidedly weaker than those around the world, particularly for Europe. Momentum strategies exhibit a unique pattern of seasonality in January. Many of the well-known strategies such as long-horizon and short-horizon return reversals, the size effect, and the book-to-market effect are significantly stronger in January than in any other calendar month. In contrast, Jagadeesh and Titman found that the momentum strategy earns negative returns in January, but earns significantly positive returns in every calendar month outside of January.

A potential source of momentum profits is cross-sectional dispersion in expected returns. Intuitively, since realized returns contain a component related to expected returns, securities that experience relatively high returns in one period can be expected to have higher than average returns in the following period. Momentum strategies can also benefit from a positive serial correlation in factor returns. With a positive serial correlation, large factor realizations in one period will be followed by higher-than-average factor realizations in the next period. The momentum strategy will tilt towards high beta stocks following periods of large factor realizations, and hence it will benefit from the higher expected future factor realizations (Jegadeesh and Titman 2011).

Momentum profits can also potentially arise if stock prices react to common factors with some delay. Intuitively, if stock prices react with a delay to common information, investors will be able to anticipate future price movements based on current factor realizations and devise profitable trading strategies. Jegadeesh and Titman (1995) showed that in some situations such delayed reactions will result in profitable contrarian strategies, but in other situations, it will result in profitable momentum strategies. Momentum strategy with individual stocks is more profitable when the ranking period and 
holding period are not contiguous than when they are contiguous. When the holding period and the ranking period are contiguous, the profits to the momentum strategy are attenuated by the negative serial correlation in returns induced by the bid-ask spreads, and by the short-horizon return reversals. In contrast, industry momentum profits entirely disappear for the six-month ranking period when the ranking period and the holding period are not contiguous. The industry momentum seems to benefit from the positive firstorder serial correlation in portfolio returns while the individual stock momentum is reduced by short-horizon return reversals (Jagadeesh and Titman, 2011).

\subsection{Empirical literature}

Avramov et.al (2013) studied time-varying momentum payoffs and illiquidity using data spanning from 1926 to 2011 for all common stocks listed on NYSE, AMEX, and NASDAQ obtained from the Centre for Research in Security Prices (CRSP). They found out that the profitability of the momentum trading strategy strongly varies with the state of market illiquidity, consistent with behavioural models of investor's expectations. Periods of high market illiquidity are often followed by low, and often massively negative, momentum payoffs. The predictive power of market illiquidity uniformly exceeds that of competing for state variables, including market states, market volatility, and investor sentiment, and is robust in both in- and out-of-sample experiments as well as among large-cap firms. Market illiquidity also captures the cross-sectional dispersion in momentum payoffs implemented among high versus low volatility stocks. Focusing on the most recent decade, while momentum profitability is non-existent unconditionally, it regains significance in periods of low market illiquidity, and market illiquidity similarly affects the profitability of the earnings momentum trading strategy.

Chen (2016) studied the semi-varying momentum payoffs and illiquidity. The researcher obtains raw data from Thomson DataStream of all stocks listed on the FTSE All-Share index. The sample spans the period 19902013. The author extracts datatype including daily market value (share price multiplied by the number of ordinary shares in issue); return index (a theoretical growth in value of a share-holding over a specified period); and unadjusted closing price. At the end of each month, the total number of shares outstanding, the return index, and the market value of each stock are obtained. Stocks are kept if they existed for at least three years before the year start. Chen (2016) found that periods of high market illiquidity are followed by low momentum profits, and very often negative returns. In the presence of aggregate illiquidity, the power of the competing state variables (for example, the down-market condition) disappears. The study also captures significant momentum crashes and the increase of liquidity risks during the financial 
crisis and concludes illiquidity shocks predict both momentum and value investment returns.

Aziz and Ansari (2014) studied momentum and illiquidity premium in the Indian stock market, using data from the Centre for monitoring the Indian Economy (CMIE). The sample consisted of daily and monthly data for S\&P BSE500 stocks over the period April 2000 to March 2012. They found out that price momentum strategy could be enhanced by conditioning on past illiquidity. Illiquid winners outperform liquid winners by an average of $2.7 \%$ per month. Compared with momentum, the illiquidity effect is more pronounced. Further evidence presented a significant illiquidity premium in India for the period 2000-2012. A momentum strategy that buys previous sixmonth winners and sells losers earns substantial returns for the next six months. They conclude that exploring the alternate liquidity proxies and momentum strategy may shed light on the dynamic interaction between illiquidity and momentum.

Orlov (2016) empirically examined the effect of equity market illiquidity on the excess returns of currency momentum and carry trade strategies. The sample consists of end-of-month observations of spot exchange rates, one-month forward exchange rates, and corresponding bid-ask spreads for the period from January 1976 to January 2014. Results show that equity market illiquidity explains the evolution of currency momentum strategy payoffs, but not carry trade. Returns on currency momentum are low following months of high equity market illiquidity. However, in the recent decade, illiquidity positively predicts the associated payoffs. The findings withstand various robustness checks and are economically significant, approximating in value to one-third of average monthly profits.

Butt and Virk (2017) studied momentum profits and time-varying illiquidity effect, the collected data from daily and monthly files for all common stocks with share code 10 or 11 listed on NYSE, AMEX, and NASDAQ or the period of July 1963- December 2012. Their show that the contemporaneous effect of systematic illiquidity dominates the opposite prediction of lagged systematic illiquidity and retains its significance even if variables capturing the time-varying exposures of momentum returns to market risk are included in the analysis.

From the preceding studies on momentum and illiquidity, these studies conclude that illiquidity has a time-varying effect on momentum strategies, however, none of the study has looked at the moderating effect of illiquidity on momentum, and therefore this study seeks to fill this gap.

\section{Methodology}

Longitudinal research design was used for this study to examine the causal inference that can be made in certain cases by analyzing data collected 
over set time span which offers researchers the opportunity to gauge trends. Purposively, the study used monthly transactions on the 20 equities used in the formulation of the NSE 20 share index over the period between Jan 2009 and up to March 2018, which formed 111 data points. The stocks in the index were used because they represent a particular portion of the broader market and an index is imaginary portfolio of securities, furthermore they actively trade daily in the exchange, therefore, giving a true picture of the market. The period of 9 years and 3 months was selected and would capture milestones that affect the capital market, including the financial crisis of 2008, change of governance over this period, and the financial recession in 2009-2011.

This study adopted Amihud (2002) illiquidity model to measure illiquidity, which uses the average ratio of daily absolute stock return to its Shillings trading volume. This absolute price change against trading volume can be interpreted as the price impact flow.

$$
I L L I Q_{i}=\text { Monthly Average Daily Returns }\left[\frac{\text { Absolute value }(\text { Stock return })}{\text { Shillings Volume }}\right]
$$

Momentum indicator the relative strength indicator (RSI) was used, developed by Welles Wilder (1978) It is a momentum indicator, or oscillator, that measures the relative internal strength of a stock or market against itself, instead of comparing one asset with another, or a stock with a market. The formula for the RSI is as follows:

$$
R S I=100-\frac{[100]}{1+R S}
$$

where $\mathrm{RS}=$ the average of $\mathrm{x}$ days' up closes divided by the average of $\mathrm{x}$ days down closes

\subsection{Model specification}

The following model was used

$$
\begin{aligned}
& R_{i, t}=\gamma_{t}+\gamma_{t} \widehat{\beta_{P, t-1}}+\gamma_{t} \text { Size }_{i, t-1}+\gamma_{t} B / M_{i, t-1}+\gamma_{t} I L L I Q_{i, t-1} \\
& +\gamma_{t} \text { MOMENT }_{i, t-1}+\gamma_{t} \text { ILLIQ.MOMENT }_{i, t-1}+\varepsilon_{i, t} .
\end{aligned}
$$

Where: -

$R_{i, t}$ : denotes the excess return of stock $i$ of montht.

$\widehat{\beta_{P, t-1}}$ : denotes stock beta, which is the same for all stocks in the portfolio $\mathrm{P}$ using the data for the previous 12 months.

Size $_{i, t-1}$ : is the log of market value of equity for month $t-1$.

$B / M_{i, t-1}$ : is the book value over market value for month $t-1$.

$I L L I Q_{i, t-1}$ : is the measure of illiquidity of the stock $i$ of month $t-1$. Amihud Ratio was used for this measure.

$M_{M O M E N T_{i, t-1}}$ : is the measure of momentum of the stock $i$ of month $t-1$ Relative Strength Index was used as a measure for momentum.

$\varepsilon_{i, t}:$ is the error term where $\varepsilon_{t} \sim \operatorname{IId}\left(0, \sigma_{\varepsilon}^{2}\right)$ 
$\gamma_{t}$ ILLIQ. MOMENT $_{i, t-1}$ is the Moderator Variable.

\section{Results and Discussion}

We present results first without the moderator and later after including the moderator to measure the change in $\mathrm{R}^{2}$ to confirm the presence of moderation. The unit root test results are shown in table 4.1

Table 4.1 Unit Root Test Results Without Moderator

\begin{tabular}{|c|c|c|c|c|}
\hline \multirow[t]{3}{*}{ Variables } & \multicolumn{2}{|c|}{$\begin{array}{c}\text { Augmented Dickey-Fuller } \\
\text { (ADF) Test } \\
\end{array}$} & \multicolumn{2}{|c|}{ Phillips Perron (PP)Test } \\
\hline & \multicolumn{2}{|c|}{ At levels } & \multirow[b]{2}{*}{ Intercept } & \multirow[b]{2}{*}{$\begin{array}{l}\text { Intercept \& } \\
\text { Trend } \\
\end{array}$} \\
\hline & Intercept & $\begin{array}{c}\text { Intercept \& } \\
\text { Trend } \\
\end{array}$ & & \\
\hline & t-Statistic & $\mathrm{t}$-Statistic & t-Statistic & $\mathrm{t}$-Statistic \\
\hline RETURNS & $\begin{array}{c}-4.7999 * * \\
(0.0001)\end{array}$ & $\begin{array}{c}-4.7768 * * \\
(0.0009)\end{array}$ & $\begin{array}{c}-8.1793 * * \\
(0.0000)\end{array}$ & $\begin{array}{c}-8.2914 * * \\
(0.0000)\end{array}$ \\
\hline BETA & $\begin{array}{l}-1.5218 \\
(0.5190)\end{array}$ & $\begin{array}{l}-2.1997 \\
(0.4847)\end{array}$ & $\begin{array}{c}-1.564 \\
(0.4975)\end{array}$ & $\begin{array}{c}-2.2792 \\
0.4413\end{array}$ \\
\hline SIZE & $\begin{array}{l}-0.8134 \\
(0.8107)\end{array}$ & $\begin{array}{l}-2.1307 \\
(0.5221)\end{array}$ & $\begin{array}{l}-2.0771 \\
(0.2543)\end{array}$ & $\begin{array}{l}-2.6242 \\
(0.2707)\end{array}$ \\
\hline PRICE_BOOK & $\begin{array}{l}-1.6597 \\
(0.4488)\end{array}$ & $\begin{array}{l}-1.6527 \\
(0.7654)\end{array}$ & $\begin{array}{l}-1.6987 \\
(0.4291)\end{array}$ & $\begin{array}{l}-1.6918 \\
(0.7485)\end{array}$ \\
\hline ILLIQ & $\begin{array}{l}-2.6921^{*} \\
(0.0787)\end{array}$ & $\begin{array}{l}-2.971 \\
0.1453\end{array}$ & $\begin{array}{c}-8.4297 * * \\
(0.0000)\end{array}$ & $\begin{array}{c}-8.9247 * * \\
(0.0000)\end{array}$ \\
\hline MOMEN & $\begin{array}{c}-5.5404 * * \\
(0.0000)\end{array}$ & $\begin{array}{c}-5.5241 * * \\
0.0001\end{array}$ & $\begin{array}{l}-6.9163^{* *} \\
(0.0000)\end{array}$ & $\begin{array}{c}-7.0439 * * \\
(0.0000)\end{array}$ \\
\hline \multicolumn{5}{|c|}{ At first difference } \\
\hline$\triangle \mathrm{BETA}$ & $\begin{array}{c}-10.3554 * * \\
(0.0000)\end{array}$ & $\begin{array}{c}-10.3305^{* *} \\
(0.0000)\end{array}$ & $\begin{array}{c}-10.3554 * * \\
(0.0000)\end{array}$ & $\begin{array}{c}-10.3305^{* *} \\
(0.0000)\end{array}$ \\
\hline$\triangle \mathrm{SIZE}$ & $\begin{array}{l}-5.6554 * * \\
(0.0000)\end{array}$ & $\begin{array}{l}-5.4347 * * \\
(0.0001)\end{array}$ & $\begin{array}{l}-10.3988^{* *} \\
(0.0000)\end{array}$ & $\begin{array}{c}-10.3739 * * \\
(0.0000)\end{array}$ \\
\hline$\triangle$ PRICE_BOOK & $\begin{array}{c}-10.3572 * * \\
(0.0000)\end{array}$ & $\begin{array}{c}-10.3096^{* *} \\
(0.0000)\end{array}$ & $\begin{array}{c}-10.3572 * * \\
(0.0000)\end{array}$ & $\begin{array}{c}-10.3096^{* *} \\
(0.0000)\end{array}$ \\
\hline$\triangle$ ILLIQ & $\begin{array}{c}-14.6094 * * \\
(0.0000)\end{array}$ & $\begin{array}{c}-14.5361^{* *} \\
(0.0000)\end{array}$ & $\begin{array}{c}-31.5872^{* *} \\
(0.0001)\end{array}$ & $\begin{array}{c}-31.3414^{* *} \\
(0.0001)\end{array}$ \\
\hline$\triangle \mathrm{MOMEN}$ & $\begin{array}{l}-8.1658^{* *} \\
(0.0000)\end{array}$ & $\begin{array}{c}-8.0981 * * \\
(0.0000)\end{array}$ & $\begin{array}{l}-21.304 * * \\
(0.0000)\end{array}$ & $\begin{array}{c}-21.1394 * * \\
(0.0000)\end{array}$ \\
\hline
\end{tabular}

Notes: - The Null hypothesis is that the series has a unit root. For ADF and PP the Probability based on MacKinnon (1996) one-sided p-values. Lag Length based on AIC. (*) Significant at the $10 \%$; (**) Significant at the 5\%; (***) Significant at the $1 \%$. The parenthesized values represent the probability while $\Delta$ denotes the first difference

Results in Table indicate based on the ADF and PP that not all the variables are stationary at levels, interestingly RETURNS and MOMEN are stationary at levels in both ADF and PP where their p-values at order zero are less than 0.05 . Using the PP test the variable ILLIQ is stationary at $I(0)$ leading 
to the rejection of the null hypothesis. For the other variables we accept the null hypothesis $\delta=0$, these variables have to be differenced that is integrated of order one $I(1)$ to achieve stationarity. At the first difference, all the variables in both ADF and PP test have $\mathrm{p}$ values less than 0.05 confirming that they are stationary and therefore rejecting the null hypothesis $(\delta=0)$ that there is a unit root in the variables.

To test whether there is a co-integration relationship between the variables, the Johansen cointegration test was used. Table 4.2 shows the results

Table 4.2 Johansen Cointegration test

\begin{tabular}{|c|c|c|c|c|}
\hline \multicolumn{5}{|c|}{ Unrestricted Cointegration Rank Test (Trace) } \\
\hline $\begin{array}{c}\text { Hypothesized } \\
\text { No. of CE(s) }\end{array}$ & Eigenvalue & $\begin{array}{c}\text { Trace } \\
\text { Statistic }\end{array}$ & $\begin{array}{c}0.05 \\
\text { Critical Value }\end{array}$ & Prob.** \\
\hline None * & 0.435847 & 187.0324 & 125.6154 & 0.0000 \\
\hline At most $1 *$ & 0.419553 & 124.6376 & 95.75366 & 0.0001 \\
\hline At most 2 & 0.246221 & 65.34642 & 69.81889 & 0.1080 \\
\hline At most 3 & 0.162159 & 34.53693 & 47.85613 & 0.4727 \\
\hline At most 4 & 0.094233 & 15.25190 & 29.79707 & 0.7635 \\
\hline At most 5 & 0.030858 & 4.463782 & 15.49471 & 0.8628 \\
\hline At most 6 & 0.009562 & 1.047222 & 3.841466 & 0.3061 \\
\hline
\end{tabular}

Trace test indicates 2 cointegrating eqn(s) at the 0.05 level

* denotes rejection of the hypothesis at the 0.05 level

**MacKinnon-Haug-Michelis (1999) p-values

Unrestricted Cointegration Rank Test (Maximum Eigenvalue)

\begin{tabular}{ccccc}
\hline \hline $\begin{array}{c}\text { Hypothesized } \\
\text { No. of CE(s) }\end{array}$ & Eigenvalue & $\begin{array}{c}\text { Max-Eigen } \\
\text { Statistic }\end{array}$ & $\begin{array}{c}0.05 \\
\text { Critical Value }\end{array}$ & Prob.** \\
\hline \hline None $*$ & 0.435847 & 62.39476 & 46.23142 & 0.0005 \\
At most 1 $*$ & 0.419553 & 59.29122 & 40.07757 & 0.0001 \\
At most 2 & 0.246221 & 30.80949 & 33.87687 & 0.1113 \\
At most 3 & 0.162159 & 19.28503 & 27.58434 & 0.3928 \\
At most 4 & 0.094233 & 10.78811 & 21.13162 & 0.6684 \\
At most 5 & 0.030858 & 3.416560 & 14.26460 & 0.9152 \\
At most 6 & 0.009562 & 1.047222 & 3.841466 & 0.3061 \\
\hline \hline
\end{tabular}

Max-eigenvalue test indicates 2 cointegrating eqn(s) at the 0.05 level $*$ denotes rejection of the hypothesis at the 0.05 level

**MacKinnon-Haug-Michelis (1999) p-values

Table 4.3 Normalized cointegrating equation

\begin{tabular}{cccccc} 
RETURNS & BETA & SIZE & PRICE_BOOK & ILLIQ & MOMEN \\
1.000000 & 0.007835 & 0.000976 & 0.008866 & 4884.185 & 0.000117 \\
& $(0.00316)$ & $(0.00339)$ & $(0.00264)$ & $(1876.09)$ & $(6.0 \mathrm{E}-05)$ \\
\hline
\end{tabular}


From Table 4.2 the null hypothesis of no cointegration $(r=0)$ against the alternative of presence of one or more cointegrating vector is rejected at the $5 \%$ level of significance in both techniques (trace test and maximum eigenvalue). This implies there exist a long run relationship between RETURNS BETA SIZE PRICE_BOOK ILLIQ MOMEN. Based on this finding the study applied Vector Error Correction Model of RETURNS BETA SIZE PRICE_BOOK ILLIQ MOMEN. Table 4.3 shows the normalized cointegrating equation results which implied that in the long run all the variables have a positive impact on the returns of equities in the Kenyan capital market.

\subsection{Vector Error Correction Model (VECM)}

Table 4.4 (see appendix I) shows results of Vector Error Correction estimates. The following equation was derived for error correction model $\Delta$ Returns $_{t}=-0.464557$ ect $_{t-1}-0.218114 \Delta$ Returns $_{t-1}-0.005332 \Delta$ Beta $_{t-1}$ $+$

$\begin{array}{lcc}(-5.49213) & (-1.51922) & (1.02977) \\ 0.003129 \Delta \text { Size }_{t-1} & -0.007217 \Delta \text { Pricetobook }_{t-1}+ \\ \begin{array}{ll}(0.56563) & (-1.59003) \\ 458.6135 \Delta \text { Illiq }_{t-1} & +0.0000313 \Delta \text { Momen }_{t-1}+0.0000881 . \\ (4.4) & \\ (0.61869) & (0.55459)\end{array}\end{array}$

Table 4.4 (see Appendix I) demonstrates that the variables are statistically insignificant at a 5\% level apart from the error correction term as shown in equation 4.4 that represents the short-term relationship of the variables.

The coefficient of the Error Correction term is negative and statistically significant, indicating there is the convergence of short-run adjustment dynamics toward the long-run equilibrium. This further demonstrates that the previous year's deviation from the long-run equilibrium is corrected in the current year at an adjustment speed of $46.7 \%$. Ceteris Paribus a percentage increase in BETA is associated with 0.005332 percent decrease in RETURNS in the short run. A percentage increase in SIZE will lead to a $0.003129 \%$ increase in Returns in the short run, further a percentage increase in Price to Book Ratio is linked to a $0.007217 \%$ decrease in returns in the short-run. A percentage increase in ILLIQ is associated with a $458.61 \%$ increase in Returns in the short-run and in the case of MOMEN a percentage increase in MOMEN is linked to a $0.0000313 \%$ increase in returns in the short run. 
Table 4.5. Least Square output for long run model

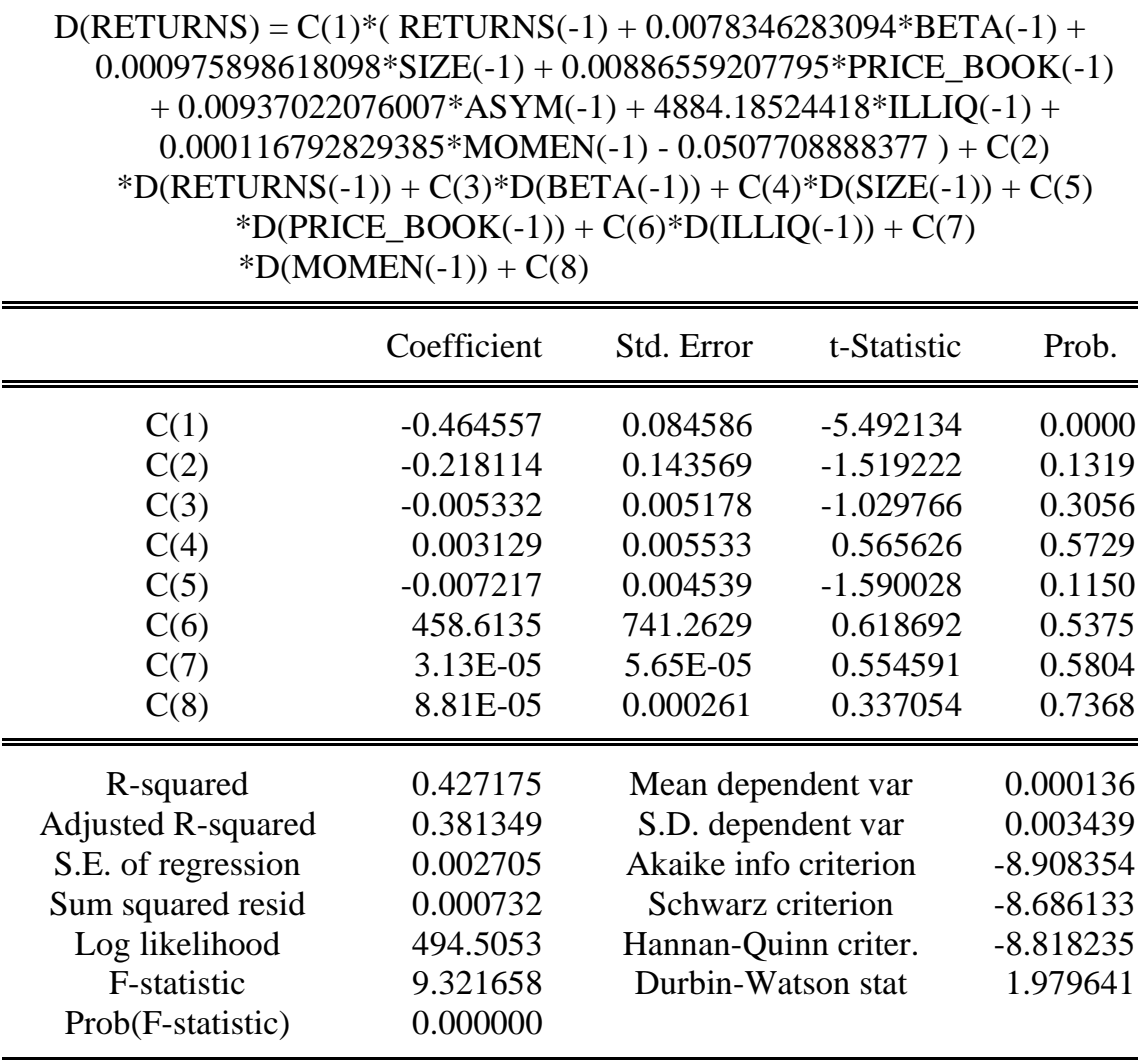

For Long-run coefficient the following equation was estimated.

$$
\begin{gathered}
\text { ECT }_{t-1}=1.00000 \text { Returns }_{t-1}+0.007835 \text { Beta }_{t-1}+0.000976 \text { Size }_{t-1}+ \\
(2.48029) \\
\text { 0.008866PricetoBook } \\
t-1+4884.185 \text { Illiq }_{t-1}+ \\
(3.36190) \\
0.000117 \text { Momen }_{t-1}-0.050771
\end{gathered}
$$

(1.95410)

Table 4.5 convey that the long-run coefficient C (1) is negative and significant which shows long-run causality between Returns and the independent variables (BETA, SIZE, PRICETOBOOK, ILLIQ and MOMEN). The adjusted R-squared is 0.381329 , which means that $38.13 \%$ of the model is explained by the independent variables. Durbin Watson static is greater than the $\mathrm{R}^{2}$ stipulating that the model is free from serial correlation hence not spurious.

To establish the moderating effect of illiquidity on the relationship between momentum and equity returns in the Kenyan Capital markets. 
The study carried out a unit root test to check for non-stationarity and cointegration tests to check for long-run relationship between the variables in the presence of a moderator variable.

\subsection{Unit root Tests}

The Augmented Dickey fuller tests and Phillips Perron tests were used to test for non-stationarity. Table $\mathbf{4 . 6}$ shows the summary at levels and first difference.

Table 4.6 Unit Root Tests with Moderator

\begin{tabular}{|c|c|c|}
\hline \multirow[t]{3}{*}{ Variables } & $\begin{array}{l}\text { Augmented Dickey Fuller } \\
\text { (ADF) Test }\end{array}$ & Phillips Perron (PP)Test \\
\hline & Intercept & Intercept \\
\hline & $\mathrm{t}$-Statistic & t-Statistic \\
\hline RETURNS & $\begin{array}{c}-4.7999 * * \\
(0.0001)\end{array}$ & $\begin{array}{c}-8.1793 * * \\
(0.0000)\end{array}$ \\
\hline BETA & $\begin{array}{l}-1.5218 \\
(0.5190)\end{array}$ & $\begin{array}{c}-1.564 \\
(0.4975)\end{array}$ \\
\hline SIZE & $\begin{array}{l}-0.8134 \\
(0.8107)\end{array}$ & $\begin{array}{l}-2.0771 \\
(0.2543)\end{array}$ \\
\hline PRICE_BOOK & $\begin{array}{l}-1.6597 \\
(0.4488)\end{array}$ & $\begin{array}{l}-1.6987 \\
(0.4291)\end{array}$ \\
\hline ILLIQ & $\begin{array}{c}-2.6921 * \\
(0.0787)\end{array}$ & $\begin{array}{c}-8.4297 * * \\
(0.0000)\end{array}$ \\
\hline MOMEN & $\begin{array}{c}-5.5404^{* *} \\
(0.0000)\end{array}$ & $\begin{array}{c}-6.9163^{* *} \\
(0.0000)\end{array}$ \\
\hline ILLIQ.MOMEN & $\begin{array}{l}-2.7988 \\
(0.0618) \\
\end{array}$ & $\begin{array}{c}-9.1934 * * \\
(0.0000)\end{array}$ \\
\hline$\triangle$ RETURNS & $\begin{array}{c}-5.1919 * * \\
(0.0000)\end{array}$ & $\begin{array}{c}-21.8464 * * \\
(0.0000)\end{array}$ \\
\hline$\triangle \mathrm{BETA}$ & $\begin{array}{c}-10.3554 * * \\
(0.0000)\end{array}$ & $\begin{array}{c}-10.3554 * * \\
(0.0000)\end{array}$ \\
\hline$\Delta$ SIZE & $\begin{array}{c}-5.6554 * * \\
(0.0000)\end{array}$ & $\begin{array}{c}-10.3988 * * \\
(0.0000)\end{array}$ \\
\hline$\triangle$ PRICE_BOOK & $\begin{array}{c}-10.3572 * * \\
(0.0000)\end{array}$ & $\begin{array}{c}-10.3572 * * \\
(0.0000)\end{array}$ \\
\hline$\triangle \mathrm{ILLIQ}$ & $\begin{array}{c}-14.6094 * * \\
(0.0000)\end{array}$ & $\begin{array}{l}-31.5872 * * \\
(0.0001)\end{array}$ \\
\hline$\triangle \mathrm{MOMEN}$ & $\begin{array}{c}-8.1658 * * \\
(0.0000)\end{array}$ & $\begin{array}{c}-21.304 * * \\
(0.0000)\end{array}$ \\
\hline$\triangle$ ILLIQ.MOMEN & $\begin{array}{c}-15.030 * * \\
(0.0000) \\
\end{array}$ & $\begin{array}{c}-40.087 * * \\
(0.0001) \\
\end{array}$ \\
\hline
\end{tabular}

Notes: - The Null hypothesis is that the series has a unit root. For ADF and PP the Probability based on MacKinnon (1996) one-sided p-values. Lag Length based on AIC. (*) Significant at the 10\%; (**) Significant at the 5\%; (***) Significant at the 1\%. The parenthesized values represent the probability while $\Delta$ denotes the first difference 
Table 4.6 shows that not all variables are stationary at levels with the exception of Returns and Momentum. However, at first difference all variables become stationary.

\subsection{Johannsen Tests with Moderator}

Johansen cointegration test was also performed, and the results are as shown below.

Table 4.7 Johannsen test with moderator Variable

\begin{tabular}{ccccc}
\hline \multicolumn{5}{c}{ Unrestricted Cointegration Rank Test (Trace) } \\
\hline \hline $\begin{array}{c}\text { Hypothesized } \\
\text { No. of CE }(\mathrm{s})\end{array}$ & Eigenvalue & $\begin{array}{c}\text { Trace } \\
\text { Statistic }\end{array}$ & $\begin{array}{c}0.05 \\
\text { Critical Value }\end{array}$ & Prob.** \\
\hline \hline None * & 0.542852 & 264.0296 & 159.5297 & 0.0000 \\
At most 1 $*$ & 0.429688 & 178.7101 & 125.6154 & 0.0000 \\
At most 2 & 0.383166 & 117.4987 & 95.75366 & 0.0007 \\
At most 3 & 0.247039 & 64.83482 & 69.81889 & 0.1171 \\
At most 4 & 0.158084 & 33.90700 & 47.85613 & 0.5069 \\
At most 5 & 0.093213 & 15.15076 & 29.79707 & 0.7702 \\
At most 6 & 0.030504 & 4.485342 & 15.49471 & 0.8608 \\
At most 7 & 0.010119 & 1.108609 & 3.841466 & 0.2924 \\
\hline \hline
\end{tabular}

Trace test indicates 3 cointegrating eqn(s) at the 0.05 level * denotes rejection of the hypothesis at the 0.05 level **MacKinnon-Haug-Michelis (1999) p-values

Unrestricted Cointegration Rank Test (Maximum Eigenvalue)

\begin{tabular}{ccccc}
\hline \hline $\begin{array}{c}\text { Hypothesized } \\
\text { No. of CE(s) }\end{array}$ & Eigenvalue & $\begin{array}{c}\text { Max-Eigen } \\
\text { Statistic }\end{array}$ & $\begin{array}{c}0.05 \\
\text { Critical Value }\end{array}$ & Prob.** \\
\hline \hline None * & 0.542852 & 85.31949 & 52.36261 & 0.0000 \\
At most 1 & 0.429688 & 61.21141 & 46.23142 & 0.0007 \\
At most 2 & 0.383166 & 52.66390 & 40.07757 & 0.0012 \\
At most 3 & 0.247039 & 30.92781 & 33.87687 & 0.1081 \\
At most 4 & 0.158084 & 18.75624 & 27.58434 & 0.4335 \\
At most 5 & 0.093213 & 10.66542 & 21.13162 & 0.6806 \\
At most 6 & 0.030504 & 3.376733 & 14.26460 & 0.9186 \\
At most 7 & 0.010119 & 1.108609 & 3.841466 & 0.2924 \\
\hline \hline
\end{tabular}

Max-eigenvalue test indicates 3 cointegrating eqn(s) at the 0.05 level $*$ denotes rejection of the hypothesis at the 0.05 level **MacKinnon-Haug-Michelis (1999) p-values

From Table 4.7 the results demonstrate at least one cointegrating equation and therefore the null hypothesis of no cointegration $(r=0)$ against the alternative of the presence of one or more cointegrating vectors is rejected at the $5 \%$ level of significance in both techniques (trace test and maximum 
eigenvalue). Having confirmed the presence of a cointegrating equation, a vector error correction model was estimated this time including the moderator variable ILLIQ.MOMEN to examine the moderation effect. The change in $\mathrm{R}^{2}$ was then used to assess moderation. A significant change in $\mathrm{R}^{2}$ was adjudged to confirm moderation

Table 4.8 Least Square output for long run model with moderator

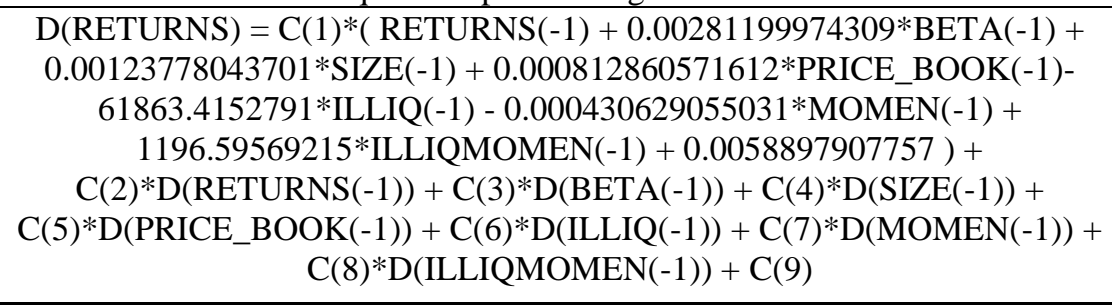

\begin{tabular}{crrrr}
\hline \hline & Coefficient & Std. Error & t-Statistic & Prob. \\
\hline \hline C(1) & -0.850480 & 0.153815 & -5.529232 & 0.0000 \\
C(2) & -0.042726 & 0.153063 & -0.279142 & 0.7807 \\
C(3) & 0.001656 & 0.005437 & 0.304592 & 0.7613 \\
C(4) & 0.002252 & 0.005515 & 0.408352 & 0.6839 \\
C(5) & -0.000247 & 0.004689 & -0.052780 & 0.9580 \\
C(7) & -23189.56 & 7708.984 & -3.008122 & 0.0033 \\
C(8) & -0.000169 & $6.88 E-05$ & -2.459382 & 0.0157 \\
C(9) & 437.9330 & 144.4993 & 3.030693 & 0.0031 \\
C(10) & 0.000154 & 0.000261 & 0.588000 & 0.5579 \\
\hline R-squared & 0.433923 & Mean dependent var & 0.000136 \\
Adjusted R-squared & 0.382461 & S.D. dependent var & 0.003439 \\
S.E. of regression & 0.002703 & Akaike info criterion & -8.901856 \\
Sum squared resid & 0.000723 & Schwarz criterion & -8.654944 \\
Log likelihood & 495.1512 & Hannan-Quinn criter. & -8.801724 \\
F-statistic & 8.431982 & Durbin-Watson stat & 1.990402 \\
Prob(F-statistic) & 0.000000 & & & \\
\hline \hline
\end{tabular}

Table 4.8 indicates the long-run model inclusive of the moderator ILLIQ.MOMEN the results demonstrate coefficient $\mathrm{C}(1)$ is negative and significant which shows long-run causality between Returns and the independent variables (BETA, SIZE, PRICETOBOOK, ILLIQ, MOMEN and ILLIQ.MOMEN). A $t$-test of the regression coefficient associated with the ILLIQXMOMENT interaction term is one way to determine if there is statistical moderation. The regression coefficient associated with the interactive effect of Illiquidity and Momentum on equity returns was significant at 0.05 level $\left(\gamma_{\mathrm{t}}=1196, t\right.$ statistic $\left.=3.030693, p=0.0031\right)$ The significant finding suggests that the effect of momentum on equity returns is affected by or moderated by, Illiquidity (i.e., there was significant moderation). The R- squared was 0.433923 indicating that $43.3 \%$ of the model 
is explained by independent variables. Further $\mathrm{R}^{2}$ change of 0.006 i.e., 0.4339 0.427 was significant at a $0.05 \%$ level. Therefore, the null hypothesis that illiquidity moderates the relationship between momentum and equity returns were accepted. From the preceding results, the study confirmed that illiquidity moderates the effect of momentum on equity returns in that presence of illiquidity increases the effect of momentum on equity returns. This is consistent with a study by Chen (2016) who found that periods of high market illiquidity are followed by low momentum profits, and very often negative returns. This can be attributed to increased transaction costs which affect the probability of momentum strategy. The study is also consistent with (Orlov, 2016) who agreed that that equity market illiquidity explains the evolution of currency momentum strategy payoffs. Absalonsen and Vas (2014) attributed a stronger momentum effect in small stocks to due to illiquidity which means that their bid to spread is higher since they tend to be traded less which makes them harder to close position.

\section{Conclusion}

This paper examined the moderating effect of illiquidity on relationship between momentum and equity returns. First, the study established that momentum affects equity returns before and after including the moderator, the two variables are cointegrated, indicating that they move together in the long-run, while experiencing short-lived deviations from the long-run relationship. The Error Correction Model (ECT) is significant and negative indicating that although the relationship between momentum and equity returns experiences the short-run e ephemeral deviations, the system reverts to its long-run equilibrium position.

Secondly, the null hypothesis tested was accepted at a $0.05 \%, p=$ 0.0031 significant level drawing inference that illiquidity moderates the relationship between momentum and equity returns in Kenyan Capital markets significantly. By conditioning past illiquidity an investor may be able to earn significant returns by applying momentum strategy, this goes to show the effect of illiquidity as a moderator variable on the relationship between momentum and returns.

Based on these findings fund managers while using momentum strategies in their portfolio construction should focus more on analysing the behaviour of illiquidity over the past year to maximize equity returns. The use of technology motivates the investor to identify the momentum opportunities that exist within the capital market therefore, further studies should be carried out to determine whether technology moderates or mediates the relationship between momentum and equity returns. 


\section{References:}

1. Acharya, V. V. \& Pedersen L. H. (2005). Asset pricing with liquidity risk. Journal of Financial Economics 77, 375-410.

2. Adesina, (2018) Africa Financial Market Index 2018, Official Monetary and Financial Institutions Forum

3. Amihud, Y. (2002). Illiquidity and stock returns: Cross-section and time-series effects. Journal of Financial Markets, 5, 31-56

4. Amihud, Y. \& H. Mendelson (1986). Asset pricing and the bid-ask spread. Journal of Financial Economics, 17, 223-249.

5. Amihud, Y., Mendelson, H., \& Pedersen, L.H., (2005). Liquidity and Asset prices. Foundations and Trends in Finance.

6. Association of Chartered Certified Accountants, (2012). The rise of Capital Markets in emerging and frontier economics

7. Avramov, D., Cheng, S., \& Hameed, A. (2013). Time-varying momentum payoffs and illiquidity. SSRN Electronic Journal.DOI: 10.2139/ssrn.2289745

8. Aziz, T., Ansari, V., (2014). Size and value premiums in the Indian stock market. Pacific Business Review International, 7(4)

9. Bacmann, J., Dubois, M. \& Isakov, D., (2001). Industries, Business Cycle and Profitability of Momentum Strategies: An International Perspective, SSRN Working Paper, SSRN id 264657

10. Berger, A., Ronen, I., \& Maskowitz, T., (2009). The case for momentum investing, AQR Capital Investment.

11. Bhojraj, S., \& Swaminathan, B., (2001). Macro momentum: Evidence of Predictability in International Equity Markets. SSRN Electronic Journal. DOI 10.1.1.200.2546

12. Butt, H., \& Virk, N., (2017) Momentum profits and time-varying illiquidity effect. Finance Research Letters 20, 253-259

13. Chacko, G., (2005). Liquidity Risk in the Corporate Bond Markets. Harvard Business School. http://dx.doi.org/10.2139/ssrn.687619.

14. Chan, K., Hameed, A., \& Tong, W., (2000). Profitability of Momentum Strategies in the International Equity Markets. The Journal of Financial and Quantitative Analysis. 35(2), 153-157.

15. Chen, J. (2016) Liquidity, Momentum and Price Bubbles: Evidence from the UK. Published Thesis Heriot-Watt University

16. Choi, J., (2014). Physical approach to price momentum and its application to momentum strategy. SUNY Stony Brook, NY

17. Capital Market Authority Kenya CMA (2018). The Capital Markets Soundness Report Volume VII Quarter 2. 2018 "Improving capital market products' uptake and tackling identified obstacles to listings"

18. Dalgaard, R. (2009). Liquidity and Stock Returns: Evidence from Denmark, Master's Thesis Copenhagen Business School. 
19. Easley, D., \& O’Hara, M., (1987). Price, Trade Size and Information In securities Markets. Journal of Financial Economics, 19, 69-90

20. Easley, D., Hvidkjear, S., \& O'Hara, M., (2002). Is information Risk a Determinant of Asset returns? Journal of Finance. 57(5), 2185-2221

21. Eleswarapu, V. R. (1997), 'Cost of transacting and expected returns in the Nasdaq market'. Journal of Finance 52, 2113-2127.

22. Eleswarapu, V. R. \& M. Reinganum (1993). The seasonal behavior of liquidity premium in asset pricing. Journal of Financial Economics 34, 373-386.

23. Fama, E., \& French, K., (2012). Size, value, and momentum in international stock returns. Journal of Financial Economics, 105 (3) $457-472$

24. Gaunt, C., \& Schinider, P., (2012). Price and earnings momentum in Australian stock returns. Journal of Accounting and finance, 52 (2), 495-517

25. Glosten, L., \& Milgrom, P., (1985). Bid Ask and transaction prices in a specialist Markmt with heterogeneously informed traders. Journal of Financial Economics, 14, 71-100

26. Gosalia, K., \& Lefebvre, R., (2013). Empirical Testing of Momentum Effect in Canadian Capital Markets. Certified General Accountants Association of Canada.

27. Griffin, J.M., Susan J., \& Spencer M. J., (2003). Momentum investing and business cycle risk: Evidence from pole to pole, Journal of Finance 58, 2515-2547.

28. Gutierrez, R., Hameed, A., \& Cooper, M., (2004). Market states and momentum. Journal of Finance, 59(3), 1345-1365

29. Hasbrouck, J. (2005). Inferring trading costs from daily data: US equities for 1962 to 2001'. Working Paper, NYU Stern.

30. Jagadeesh, N., (1990). Evident of Predictable Behaviour of Security Returns. The Journal of Finance. 45(3),881-98.

31. Jagadeesh N., \& Titman S., (1993). Returns to buying winners and selling losers: Implications for stock market efficiency, Journal of Finance 48, 65-91.

32. Jagadeesh N., \& Titman S., (1995). Overreaction, Delayed Reaction, and Contrarian Profits. Review of Financial Studies 8(4, 973-93.

33. Jagadeesh N., \& Titman S., (2011). Momentum. Annual Review of Financial Economics, 3(1), 493-509

34. Lehman, B., (1990). Fads, martingales, and market efficiency, Quarterly Journal of Economics 105, 1-28.

35. Lo, A., \& Khandani, A., (2009). Illiquidity premia in asset returns: An empirical analysis of hedge funds, mutual funds and U.S. equity portfolios. http://dx.doi.org/10.2139/ssrn.1425494 
36. Moskowitz, T., Pedersen, L., \& Asness C., (2013). Value and Momentum Everywhere. Journal of Finance, American Finance Association.

37. MSCI Kenya Index, (2020). https://www.msci.com/documents/10199/5725f9b1-5ce7-4ed5-a95e2cb0b92da407

38. Muhairi M.A., (2011). Assessing momentum investment strategies in the U.A.E. Stock Market Doctoral Thesis, University of Portsmouth

39. Nguyen, J., \& Fraulo, P., (2010). Do Industries Explain Momentum? - A Replication of Moskowitz and Grinblatt 2004. Williams College.

40. Norieka, L. \& Barauskas, J., (2010). Momentum in Mature and Emerging Markets under Different Market States: the Case of the Baltic Region. Stockholm School of Economics.

41. Nørregård, M., (2008) Momentum Investment Strategy An empirical and explorative study on price momentum- The Danish evidence. Published Msc Thesis. Copenhagen Business School.

42. Orlov, V., (2016). Currency momentum, carry trade, and market illiquidity. Journal Of Banking and Finance, 67, 1-1

43. Pástor, L, \& Stambaugh R. F., (2003), Liquidity risk and expected stock returns, Journal of Political Economy, 111, 642-685.

44. Reilly, F., \& Brown, K., (2013). Investment Analysis and portfolio management. Thomson South Western.

45. Srivastava, S., Chakravorty, G., \& Singhal, M., (2019). Momentum in the Indian Equity Markets: Positive Convexity and Positive Alpha. SSRN: $\quad$ https://ssrn.com/abstract=3345280 or http://dx.doi.org/10.2139/ssrn.3345280

46. Vayanos, D. \& Vila, J., (1999). Equilibrium interest rate and liquidity premium with transaction costs. Economic Theory 13, 509-539.

47. Vayanos, D., (1998). Transaction costs and asset prices: A dynamic equilibrium model. Review of Financial Studies 11, 1-58.

48. Vayanos, D., \& Woodley, P., (2013). An Institutional Theory of Momentum and Reversal. London School of Economics.

49. Welles Wilder Jr, J., (1978). New Concepts in Technical Trading Systems. Hunters Publishing Company, United States

50. World Bank (2020). Stock Market Capitalization to GDP for Kenya. Federal Reserve Bank of St. Louis; https://fred.stlouisfed.org/series/DDDM01KEA156NWDB. November 10, 2020.

51. Wyman, O., (2014). The Capital Markets Industry the Times They Are A-Changing', Marsh and McLennan Companies. 


\section{APPENDIX}

Table 4.4: Vector Error Correction Estimates

\begin{tabular}{|c|c|c|c|c|c|c|}
\hline Cointegrating Eq: & CointEq1 & & & & & \\
\hline RETURNS(-1) & 1.000000 & & & & & \\
\hline BETA(-1) & $\begin{array}{r}0.007835 \\
(0.00316) \\
{[2.48029]}\end{array}$ & & & & & \\
\hline SIZE(-1) & $\begin{array}{c}0.000976 \\
(0.00339) \\
{[0.28803]}\end{array}$ & & & & & \\
\hline PRICE_BOOK(-1) & $\begin{array}{c}0.008866 \\
(0.00264) \\
{[3.36190]}\end{array}$ & & & & & \\
\hline ILLIQ(-1) & $\begin{array}{c}4884.185 \\
(1876.09) \\
{[2.60338]}\end{array}$ & & & & & \\
\hline MOMEN(-1) & $\begin{array}{c}0.000117 \\
(6.0 \mathrm{E}-05) \\
{[1.95410]}\end{array}$ & & & & & \\
\hline $\mathrm{C}$ & -0.050771 & & & & & \\
\hline Error Correction: & D(RETURNS) & $\mathrm{D}$ (BETA) & D(SIZE) & D(PRICE_BOOK) & D(ILLIQ) & $\mathrm{D}(\mathrm{MOMEN})$ \\
\hline CointEq1 & -0.464557 & 0.854680 & 0.558914 & -2.521559 & $-3.33 \mathrm{E}-05$ & -1095.149 \\
\hline
\end{tabular}


European Scientific Journal, ESJ

December 2021 edition Vol.17, No.41

\begin{tabular}{|c|c|c|c|c|c|c|}
\hline & $\begin{array}{r}(0.08459) \\
{[-5.49213]}\end{array}$ & $\begin{array}{r}(2.16524) \\
{[0.39473]}\end{array}$ & $\begin{array}{c}(1.53667) \\
{[0.36372]}\end{array}$ & $\begin{array}{r}(2.46151) \\
{[-1.02440]}\end{array}$ & $\begin{array}{c}(9.0 \mathrm{E}-06) \\
{[-3.69599]}\end{array}$ & $\begin{array}{c}(231.064) \\
{[-4.73958]}\end{array}$ \\
\hline D(RETURNS(-1)) & $\begin{array}{r}-0.218114 \\
(0.14357) \\
{[-1.51922]}\end{array}$ & $\begin{array}{r}-0.570376 \\
(3.67511) \\
{[-0.15520]}\end{array}$ & $\begin{array}{r}-6.850325 \\
(2.60823) \\
{[-2.62643]}\end{array}$ & $\begin{array}{r}1.297570 \\
(4.17797) \\
{[0.31057]}\end{array}$ & $\begin{array}{c}3.91 \mathrm{E}-05 \\
(1.5 \mathrm{E}-05) \\
{[2.55513]}\end{array}$ & $\begin{array}{c}937.3972 \\
(392.191) \\
{[2.39016]}\end{array}$ \\
\hline $\mathrm{D}(\operatorname{BETA}(-1))$ & $\begin{array}{r}-0.005332 \\
(0.00518) \\
{[-1.02977]}\end{array}$ & $\begin{array}{c}0.010541 \\
(0.13255) \\
{[0.07952]}\end{array}$ & $\begin{array}{r}-0.034713 \\
(0.09407) \\
{[-0.36902]}\end{array}$ & $\begin{array}{r}-0.012713 \\
(0.15068) \\
{[-0.08437]}\end{array}$ & $\begin{array}{c}1.50 \mathrm{E}-06 \\
(5.5 \mathrm{E}-07) \\
{[2.71696]}\end{array}$ & $\begin{array}{c}-22.65109 \\
(14.1448) \\
{[-1.60138]}\end{array}$ \\
\hline $\mathrm{D}(\operatorname{SIZE}(-1))$ & $\begin{array}{c}0.003129 \\
(0.00553) \\
{[0.56563]}\end{array}$ & $\begin{array}{r}-0.010192 \\
(0.14163) \\
{[-0.07196]}\end{array}$ & $\begin{array}{r}0.045127 \\
(0.10051) \\
{[0.44897]}\end{array}$ & $\begin{array}{c}0.026134 \\
(0.16101) \\
{[0.16232]}\end{array}$ & $\begin{array}{c}-9.59 \mathrm{E}-07 \\
(5.9 \mathrm{E}-07) \\
{[-1.62588]}\end{array}$ & $\begin{array}{r}15.95879 \\
(15.1137) \\
{[1.05591]}\end{array}$ \\
\hline D(PRICE_BOOK(-1)) & $\begin{array}{r}-0.007217 \\
(0.00454) \\
{[-1.59003]}\end{array}$ & $\begin{array}{c}0.001122 \\
(0.11619) \\
{[0.00966]}\end{array}$ & $\begin{array}{r}-0.003642 \\
(0.08246) \\
{[-0.04416]}\end{array}$ & $\begin{array}{c}0.002831 \\
(0.13208) \\
{[0.02144]}\end{array}$ & $\begin{array}{r}9.30 \mathrm{E}-07 \\
(4.8 \mathrm{E}-07) \\
{[1.92073]}\end{array}$ & $\begin{array}{c}-23.02738 \\
(12.3988) \\
{[-1.85723]}\end{array}$ \\
\hline D(ILLIQ(-1)) & $\begin{array}{c}458.6135 \\
(741.263) \\
{[0.61869]}\end{array}$ & $\begin{array}{r}-25081.06 \\
(18975.0) \\
{[-1.32180]}\end{array}$ & $\begin{array}{c}6718.917 \\
(13466.5) \\
{[0.49893]}\end{array}$ & $\begin{array}{r}-417.5052 \\
(21571.3) \\
{[-0.01935]}\end{array}$ & $\begin{array}{r}-0.484982 \\
(0.07904) \\
{[-6.13590]}\end{array}$ & $\begin{array}{c}1377787 . \\
(2024919) \\
{[0.68042]}\end{array}$ \\
\hline $\mathrm{D}(\mathrm{MOMEN}(-1))$ & $\begin{array}{c}3.13 \mathrm{E}-05 \\
(5.6 \mathrm{E}-05) \\
{[0.55459]}\end{array}$ & $\begin{array}{r}0.000349 \\
(0.00145) \\
{[0.24121]}\end{array}$ & $\begin{array}{c}0.001974 \\
(0.00103) \\
{[1.92339]}\end{array}$ & $\begin{array}{r}-0.000245 \\
(0.00164) \\
{[-0.14905]}\end{array}$ & $\begin{array}{r}-8.10 \mathrm{E}-09 \\
(6.0 \mathrm{E}-09) \\
{[-1.34409]}\end{array}$ & $\begin{array}{c}-0.446504 \\
(0.15434) \\
{[-2.89301]}\end{array}$ \\
\hline $\mathrm{C}$ & $\begin{array}{c}8.81 \mathrm{E}-05 \\
(0.00026) \\
{[0.33705]}\end{array}$ & $\begin{array}{r}-0.002241 \\
(0.00669) \\
{[-0.33494]}\end{array}$ & $\begin{array}{c}0.003452 \\
(0.00475) \\
{[0.72701]}\end{array}$ & $\begin{array}{r}-0.002613 \\
(0.00761) \\
{[-0.34357]}\end{array}$ & $\begin{array}{c}8.34 \mathrm{E}-09 \\
(2.8 \mathrm{E}-08) \\
{[0.29910]}\end{array}$ & $\begin{array}{c}0.258679 \\
(0.71405) \\
{[0.36227]}\end{array}$ \\
\hline
\end{tabular}

ISSN: 1857-7881 (Print) e - ISSN 1857-7431 


\begin{tabular}{crrrrrr} 
Adj. R-squared & 0.381349 & -0.060352 & 0.023732 & -0.030989 & 0.410777 & 0.333019 \\
Sum sq. resids & 0.000732 & 0.479514 & 0.241519 & 0.619715 & $8.32 \mathrm{E}-12$ & 5460.789 \\
S.E. equation & 0.002705 & 0.069247 & 0.049145 & 0.078722 & $2.88 \mathrm{E}-07$ & 7.389715 \\
F-statistic & 9.321658 & 0.231626 & 1.328170 & 0.594220 & 10.41153 & 7.740463 \\
Log likelihood & 494.5053 & 141.0707 & 178.4481 & 127.0922 & 1491.436 & -367.9773 \\
Akaike AIC & -8.908354 & -2.423315 & -3.109139 & -2.166829 & -27.20067 & 6.917015 \\
Schwarz SC & -8.686133 & -2.201094 & -2.886918 & -1.944608 & -26.97844 & 7.139237 \\
Mean dependent & 0.000136 & -0.002218 & 0.003597 & -0.002752 & $1.32 \mathrm{E}-10$ & 0.398411 \\
S.D. dependent & 0.003439 & 0.067247 & 0.049738 & 0.077530 & $3.76 \mathrm{E}-07$ & 9.048384 \\
\hline \hline \\
Determinant resid covariance (dof adj.) \\
Determinant resid covariance \\
Log likelihood \\
Akaike information criterion
\end{tabular}

Standard errors in () \& t-statistics in [ ]

Source: Research Data, 2019 